\title{
THE IMPACT OF THE INSTITUTIONAL ENVIRONMENT ON THE SHADOW ECONOMY
}

\author{
Tural MAKHMUDOV - Maria KONOVALOVA - Olga KUZMINA - \\ Natalia PERSTENEVA
}

(Received: 13 June 2017; revision received: 16 September 2017;

accepted: 20 September 2017)

\begin{abstract}
This article aims to explore the relationship of the shadow economy with the institutional environment and develop practical recommendations for government policies around the world, and particularly in Russia. The urgency of the issue under research is caused by the existing need to study the shadow economy in order to find ways to reduce its scale and level out its negative externalities. Despite the fact that most of the papers focus on tax burden as a fundamental determinant of the shadow economy, the authors of this article believe that institutional tools can expand the boundaries of research on the content of the shadow economy as an economic category. Statistical analysis of 105 countries with different development levels revealed a stronger correlation between the quality of institutions and the size of the shadow economy than the one between total tax burden and the size of the shadow economy. The findings of this article can be useful in developing state strategies for combating the shadow economy and carrying out economic policies of the state as a whole.
\end{abstract}

Keywords: shadow economy, institutional environment, quality of institutions, trust in institutions, Russia

JEL classification indices: A13, B52, O43

Tural Makhmudov, corresponding author. Research Assistant at the Department of Economic Theory, Samara State University of Economics, Russia. E-mail: makhmudov.tural@gmail.com

Maria Konovalova, Professor at the Department of Economic Theory, Samara State University of Economics, Russia. E-mail: mkonoval@sseu.ru

Olga Kuzmina, Associate Professor at the Department of Economic Theory, Samara State University of Economics, Russia. E-mail: kuzmina@sseu.ru

Natalia Persteneva, Associate Professor at the Department of Mathematical Statistics and Econometrics, Samara State University of Economics, Russia. E-mail: persteneva_np@mail.ru 


\section{INTRODUCTION}

Shadow economy is one of the key issues hindering the economic advancement of many countries. This phenomenon is not only a private phenomenon of economic life and practices; it is a system-forming and system-supporting mechanism of social development. This is especially true for developing countries, whose economic life is full of shadow activities.

A special attention should not only be paid to the problem of eliminating the shadow economy as a socio-economic phenomenon, but rather to a reduction in its size and pernicious externalities for society as a whole. The autopoiesis of the shadow economy (its self-regulatory nature) ${ }^{1}$ is caused by imperfection of the institutional environment that determines the opportunistic behaviour of individuals to carry out market exchanges outside the legal system. Studies of the shadow economy began in the 1950s. The origin of the interest in research of this phenomenon took place after the publication of works by Kaldor (1956) and Cagan (1958). Further studies of the shadow economy dated back to the 1970s, when the article of the English anthropologist Hart (1973) was published. In his studies commissioned by the International Labour Organization, he found that a significant proportion of Ghanaian citizens employed in small and medium-sized businesses were virtually independent from the official state economy.

In the late 1970s, a key focus was on studying the shadow economy in developed countries, such as the United States (Gutmann 1977; Feige 1979). It was subsequently called shadow, illegal, emphasizing not its informal nature, but rather its concealment from controlling bodies and an attempt to bypass the established state and social institutions. In the same period, a considerable interest was gained in studies of the shadow economy of the Soviet Union (Grossman 1977; Katsenelinboigen 1977; Kornai 1980). It was discovered that despite strict centralisation of the economic system, multifarious segments of the shadow economy were operating in the country. It was acknowledged that the shadow economy existed in all types of economic systems, generating a specific format of socio-economic relations.

In present researches, the shadow economy is the subject of broad discussions in the scientific community and the interest to this issue is burgeoning, notwithstanding that there are certain difficulties associated with measuring its

1 The concept of autopoiesis refers to a system capable of reproducing and maintaining itself. The term was introduced in 1972 by Chilean biologists Humberto Maturana and Francisco Varela to define the self-maintaining chemistry of living cells. Since then the concept has been applied to the fields of cognition, systems theory and sociology. Luhmann's adapted the concept of autopoiesis to social systems (1995). 
size (Ernste 2002). Primarily, this is due to the lack of statistical data. As a matter of fact, it is practically impossible to assess the share of the shadow segment in a particular country objectively, since it requires an estimation of economic activity that is deliberately hidden by economic agents (Schneider - Williams 2013). In this regard, statistical agencies face a number of difficulties in collecting representative data for their research.

It is also worth noting that the majority of the papers focus on tax burden as a key factor determining the size of the shadow economy (Thomas 1992; Lippert - Walker 1997; Johnson 1998; Giles 1999; Schneider 2015). Nevertheless, there are also some papers that assume that in the development of the shadow economy in multifarious countries the institutional factors are crucial, even more significant than the level of tax rates (Johnson et al. 1997; Friedmann et al. 2000). In fact, according to the authors' viewpoint, institutions can more thoroughly interpret the causation of the shadow economy and pinpoint methods to combat it.

The analysis of the scientific literature devoted to the issue of the shadow economy has revealed the absence of a single methodological approach to its study, which does not allow us to formulate the essence and content of this phenomenon unequivocally. In this connection, it seems rather perplexing to single out the determinants of the shadow economy that directly have an impact on its size. We attempted to distinguish the fundamental determinants of the shadow economy and substantiate pragmatic recommendations in order to reduce its scale.

\section{THE AMBIGUOUS CONCEPT OF THE SHADOW ECONOMY}

There are certain difficulties associated with the unequivocal definition of the shadow economy in the scientific community. One of the reasons for the variations in the definition is the distinction in the methods of measuring and estimating its size.

Many researchers use the accounting and statistical approach in determining the shadow economy, linking it to GDP. For example, this methodology was followed by Feige (1980), who noted that the shadow economy is the segment of the economy that is not reflected in official statistical information. This is also the case in the study of Smith (1994), who maintained that economic agents involved in the shadow segments deliberately attempt not to be identified when calculating GDP. It should be noted that a serious downside in the application of this methodological approach may be the paucity or imperfection of information on the basis of which statistical calculations are to be carried out.

Another viewpoint on the clarification of the shadow economy is formal in which the key attention is paid to the attitude of economic agents towards the 
regulatory system. The authors who apply this method specify the desire of economic agents to bypass government regulations. Studies by Johnson et al. (1997) revealed the correlation between the degree of state control and the scale of the shadow economy. The excessive overregulation forces the citizens to go into the shadow segments.

There is also an institutional approach that combines the principles of accounting, statistical, formal and a number of other techniques. In fact, many articles were devoted to the shadow economy from the viewpoint of institutional paradigm. For example, Friedman et al. (2000), taking into account the study of 69 countries, discovered that institutions such as bureaucracy, corruption and a weak legal environment are all associated with the shadow economy. The work of Dreher et al. (2009) established that an enhancement of the institutional environment reduces the size of the shadow economy. Schneider (2013) asserted that corruption of the bureaucratic apparatus determines the quality of institutional environment and plays a fundamental role in the economic agents' decision to conduct their activities in the shadow segment.

We believe that institutional tools expand the boundaries of research of the shadow economy as an economic category. According to our viewpoint, tax moral and ethics, bureaucratic corruption, citizens' trust in government bodies that shape the quality of institutional space play an equally important role in determining the scale of the shadow economy as tax burden. In this regard, it seems that the shadow economy is a complex issue; its analysis should not be reduced to any one factor, such as the level of tax rates.

\section{MEASUREMENTS}

\subsection{Methodological issues}

The data on shadow economy are from the work of Schneider (2016), which contained data of 157 countries for the years of 1999-2013. GDP per capita figures were taken from World Economic Outlook for the years of 1980-2017. Other indicators were taken from The Global Competitiveness Report (GCR) of the World Economic Forum (Schwab 2013). Our final and complete sample contained 105 developed and developing countries for the years of 2012-2013.

The analysis contained the following indicators:

1. The size of the shadow economy (\% of GDP). The data are collected from the MIMIC (multiple-indicator multiple cause) model which was made by Schneider (2016:4), in accordance with whom "the MIMIC model takes into account simultaneously different causes and indicators that directly influence develop- 
ment of the size of the shadow economy over time." He included the following causal and indicator variables:

1) Causal variables: tax burden, regulatory burden, unemployment rate, selfemployment rate, institutional quality².

2) Indicator variables: formal economy, currency/cash outside banks, labour force participation rate.

2. Total tax rate (\% of profits). This indicator is a combination of profit tax (as a \% of profits), labour tax and contributions (as a \% of profits), and other taxes (as a \% of profits). The tax burden can be regarded as one of the fundamental reasons that promote an increase in the size of the shadow economy. In our model, tax burden is measured by total tax rate as a percentage of profit. The data are from Schwab (2013: 543), who explained that "The total tax rate measures the amount of taxes and mandatory contributions payable by a business in the second year of operation, expressed as a share of commercial profits. The total amount of taxes is the sum of five different types of taxes and contributions payable after accounting for deductions and exemptions: profit or corporate income tax, social contributions and labour taxes paid by the employer, property taxes, turnover taxes, and other small taxes."

3. Nominal GDP per capita (U.S. dollars per capita). According to our viewpoint, low GDP per capita in a country is generally associated with high incentive to work in the shadow economy. Elgin - Oztunali (2014) found that the higher GDP per capita corresponds to the smaller size of the shadow economy in countries with high level of the institutional environment. They concluded that the relationship between the shadow economy and economic development strongly interacts with proxies of institutional quality. GDP per capita is expressed in current U.S. dollars per person. The data are from World Economic Outlook (2012, 2013).

4. The institutional environment (value). Notwithstanding the significance of the tax burden, it should be noted that in some countries in spite of a high tax rate, the size of the shadow economy is not so huge compared to the other countries and this can be justified by the differences in their institutional environment (Schneider 2016). As a proxy of the institutional environment in our model, we use the value of institutions provided by The World Economic Forum, according to which "The institutional environment is determined by the legal and adminis-

2 Note that aside from the tax rate, some institutional indicators that we use as determinants of the shadow economy were already included in the calculation of the size of the shadow economy as causal variables, i.e. the tax morale, the burden of government regulation and the quality of state institutions. Nevertheless, there are also many other indicators that are not included in our calculations and that define the size of the shadow economy in Schneider's work. 
trative framework within which individuals, firms, and governments interact to generate wealth" (Schwab 2013: 4). The so-called institutional environment was made up from 21 different institutional indicators which are presented in the Appendix by averaging over these indicators. The value of the institutional environment denotes the country's score among the selected countries and ranges from a scale of 1 to 6 (6-the highest).

5. Trust in politicians (value). In a state where the citizens have little trust in the authorities, the incentive between each party to cooperate is likely to be lacking and this leads to an increase in the size of the shadow economy. For this reason, the attitude of economic agents towards legislators can be regarded as one of the factors that determine the size of the shadow economy. The indicator that was taken from the GCR and determined by asking the respondents in each country the following question under a survey (Schwab 2013: 413): "In your country, how would you rate the ethical standards of politicians? [ 1 = extremely low; $7=$ extremely high].” After the survey, the weighted average of the indicator in each country for the years 2012-2013 was calculated. The value of trust in politicians denotes the country's score among the selected countries and it ranges from a scale of 1 to 6 (6-the highest).

6. Irregular payments and bribes (value). According to Hibbs - Piculescu (2005), corrupt legislators intentionally disregard unofficial activities in order to get bribes. Furthermore, corruption itself is often an obstacle for businesses to operate within legal frameworks. For this reason it can be regarded as a determinant of the size of the shadow economy. The indicator that was taken from Schwab (2013: 414) was determined by averaging score across the five components of the following Executive Opinion Survey question: "In your country, how common is it for firms to make undocumented extra payments or bribes connected with (a) imports and exports; (b) public utilities; (c) annual tax payments; (d) awarding of public contracts and licenses; (e) obtaining favourable judicial decisions?” In each case, the answer ranged from 1 (very common) to 7 (never occurs). The value of irregular payments and bribes denotes the country's score among the selected countries and ranges from a scale of 1 to 6 (6-the highest).

It is important to note that the last two indicators, i.e. trust in politicians and irregular payments and bribes, were taken from the list of 21 indicators that make up the institutional environment. Besides, some readers may find our calculations rather tautological, because Schneider's estimations of the explained variable, i.e. the size of the shadow economy, had already taken into account the tax rate and some institutional factors, such as the burden of government regulation, tax morale, and the quality of government institutions, i.e. which are used by us as explanatory variables. 
The coefficients of Pearson correlation for quantitative variables were calculated. The significance of correlation coefficients is examined and the regression models that characterise the correlation of the shadow economy with other variables were produced.

\subsection{Results of the statistical analysis}

The hypotheses of the correlations between the size of the shadow economy with total tax rate, GDP per capita, institutional environment, trusts in politicians, irregular payments and bribes were examined. All variables are represented in quantitative value. To measure the dependency between the size of the shadow economy and the quantitative values, Pearson's correlation coefficient was applied. The results are represented in Table 1.

Table 1. Correlations of quantitative values with the size of the shadow economy

\begin{tabular}{llrr}
\hline Indicators & & 2012 & 2013 \\
\hline GDP per capita (U.S. dollars per capita) & Pearson correlation & -0.612 & -0.602 \\
& Sig. (2-tailed) & 0.000 & 0.000 \\
The institutional environment, value & Pearson correlation & -0.577 & -0.572 \\
& Sig. (2-tailed) & 0.000 & 0.000 \\
Irregular payments and bribes, value & Pearson correlation & -0.561 & -0.568 \\
& Sig. (2-tailed) & 0.000 & 0.000 \\
Total tax rate, \% of profits & Pearson correlation & 0.181 & 0.183 \\
\multirow{2}{*}{ Trust in politicians, value } & Sig. (2-tailed) & 0.064 & 0.061 \\
& Pearson correlation & -0.395 & -0.417 \\
& Sig. (2-tailed) & 0.000 & 0.000 \\
\hline
\end{tabular}

Source: Own calculations.

On the basis of these coefficients, it is possible to draw a conclusion that GDP per capita affects the size of the shadow economy more significantly than any other variables presented. Besides, the institutional environment, irregular payments and bribes also have a strong correlation with the shadow economy. Although it is said that tax burden can be regarded as the fundamental determinant of the shadow economy, the results clearly indicate that there is no significant correlation between the size of the shadow economy and total tax rate in our calculations.

For further analysis, matrices of pair coefficients of correlation were constructed (Tables 2 and 3) for the years of 2012 and 2013, respectively. It is important to note that GDP per capita has remarkably strong correlation with the institutional 
environment (0.777 in 2012 and 0.780 in 2013), trust in politicians (0.632 in 2012 and 0.673 in 2013) and irregular payments and bribes (0.795 in 2012 and 0.796 in 2013). This might indicate that higher GDP per capita generally corresponds to more developed institutional environment. However, the relationship between GDP per capita and the institutional environment does not affect the quality of the final models which are presented in Table 4.

Table 2. Matrix of pair correlation coefficients (2012)

\begin{tabular}{|c|c|c|c|c|c|c|}
\hline Variable & $\begin{array}{l}\text { The size } \\
\text { of the } \\
\text { shadow } \\
\text { economy, } \\
\% \text { of GDP }\end{array}$ & $\begin{array}{l}\text { The insti- } \\
\text { tutional } \\
\text { environ- } \\
\text { ment, } \\
\text { value }\end{array}$ & $\begin{array}{l}\text { Trust in } \\
\text { politi- } \\
\text { cians, } \\
\text { value }\end{array}$ & $\begin{array}{c}\text { Irregular } \\
\text { pay- } \\
\text { ments and } \\
\text { bribes, } \\
\text { value } \\
\end{array}$ & $\begin{array}{l}\text { Total tax } \\
\text { rate, } \% \text { of } \\
\text { profits }\end{array}$ & $\begin{array}{c}\text { GDP per } \\
\text { capita } \\
\text { (U.S. dol- } \\
\text { lars per } \\
\text { capita) }\end{array}$ \\
\hline \multirow{2}{*}{$\begin{array}{l}\text { The size of the shadow } \\
\text { economy, \% of GDP }\end{array}$} & 1 & -0.577 & -0.395 & -0.561 & 0.181 & -0.612 \\
\hline & $(-)$ & $(0.000)$ & $(0.000)$ & $(0.000)$ & $(0.064)$ & $(0.000)$ \\
\hline \multirow{2}{*}{$\begin{array}{l}\text { The institutional } \\
\text { environment, value }\end{array}$} & -0.577 & 1 & 0.862 & 0.938 & -0.098 & 0.777 \\
\hline & $(0.000)$ & $(-)$ & $(0.000)$ & $(0.000)$ & $(0.318)$ & $(0.000)$ \\
\hline \multirow{2}{*}{$\begin{array}{l}\text { Trust in politicians, } \\
\text { value }\end{array}$} & -0.395 & 0.862 & 1 & 0.747 & -0.073 & 0.632 \\
\hline & $(0.000)$ & $(0.000)$ & $(-)$ & $(0.000)$ & $(0.459)$ & $(0.000)$ \\
\hline \multirow{2}{*}{$\begin{array}{l}\text { Irregular payments and } \\
\text { bribes, value }\end{array}$} & -0.561 & 0.938 & 0.747 & 1 & -0.153 & 0.795 \\
\hline & $(0.000)$ & $(0.000)$ & $(0.000)$ & $(-)$ & $(0.119)$ & $(0.000)$ \\
\hline \multirow{2}{*}{ Total tax rate, \% profits } & 0.181 & -0.098 & -0.073 & -0.153 & 1 & -0.118 \\
\hline & $(0.064)$ & $(0.318)$ & $(0.459)$ & $(0.119)$ & $(-)$ & $(0.230)$ \\
\hline \multirow{2}{*}{$\begin{array}{l}\text { GDP per capita (U.S. } \\
\text { dollars per capita) }\end{array}$} & -0.612 & 0.777 & 0.632 & 0.795 & -0.118 & 1 \\
\hline & $(0.000)$ & $(0.000)$ & $(0.000)$ & $(0.000)$ & $(0.230)$ & $(-)$ \\
\hline
\end{tabular}

Source: Own calculations.

Note: Pair correlations are in brackets.

The institutional environment has multicollinearity with trust in politicians and irregular payments and bribes which are, in fact, logical since these two variables were taken from the list of 21 indicators that make up the institutional environment. Besides, in both cases correlations between these indicators are quite strong which is why trust in politicians and irregular payments and bribes were excluded from the final models.

Models that include total tax rate (2nd and 4th models) and exclude this indicator (1st and 3rd models) were constructed in order to compare the quality of the final model with and without this indicator (Table 5). Note that coefficients of total tax rate both in 2012 and 2013 proved to be insignificant at 95\% level of significance (nevertheless, this indicator was significant at $80 \%$ level of significance).

Analysis of standardised coefficients reveals that the shadow economy is affected less significantly by total tax rate than by any other regressors. Test of short-long regression (after adding total tax rate variable in the model) allows 
Table 3. Matrix of pair correlation coefficients (2013)

\begin{tabular}{|c|c|c|c|c|c|c|}
\hline Variable & $\begin{array}{l}\text { The size } \\
\text { of the } \\
\text { shadow } \\
\text { economy, } \\
\% \text { of } \\
\text { GDP }\end{array}$ & $\begin{array}{l}\text { The insti- } \\
\text { tutional } \\
\text { environ- } \\
\text { ment, } \\
\text { value }\end{array}$ & $\begin{array}{l}\text { Trust in } \\
\text { politi- } \\
\text { cians, } \\
\text { value }\end{array}$ & $\begin{array}{l}\text { Irregular } \\
\text { pay- } \\
\text { ments and } \\
\text { bribes, } \\
\text { value }\end{array}$ & $\begin{array}{c}\text { Total tax } \\
\text { rate, } \% \text { of } \\
\text { profits }\end{array}$ & $\begin{array}{c}\text { GDP per } \\
\text { capita } \\
\text { (U.S. dol- } \\
\text { lars per } \\
\text { capita) }\end{array}$ \\
\hline \multirow{2}{*}{$\begin{array}{l}\text { The size of the shadow } \\
\text { economy, \% of GDP }\end{array}$} & 1 & -0.572 & -0.417 & -0.568 & 0.183 & -0.602 \\
\hline & $(-)$ & $(0.000$ & $(0.000)$ & $(0.000)$ & $(0.061)$ & $(0.000)$ \\
\hline \multirow{2}{*}{$\begin{array}{l}\text { The institutional } \\
\text { environment, value }\end{array}$} & -0.572 & 1 & 0.883 & 0.941 & -0.130 & 0.780 \\
\hline & $(0.000)$ & $(-)$ & $(0.000)$ & $(0.000)$ & $(0.186)$ & $(0.000)$ \\
\hline \multirow{2}{*}{ Trust in politicians, value } & -0.417 & 0.883 & 1 & 0.775 & -0.086 & 0.673 \\
\hline & $(0.000)$ & $(0.000)$ & $(-)$ & $(0.000)$ & $(0.382)$ & $(0.000)$ \\
\hline \multirow{2}{*}{$\begin{array}{l}\text { Irregular payments and } \\
\text { bribes, value }\end{array}$} & -0.568 & 0.941 & 0.775 & 1 & -0.171 & 0.796 \\
\hline & $(0.000)$ & $(0.000)$ & $(0.000)$ & $(-)$ & $(0.082)$ & $(0.000)$ \\
\hline \multirow{2}{*}{ Total tax rate, $\%$ profits } & 0.183 & -0.130 & -0.086 & -0.171 & 1 & -0.117 \\
\hline & $(0.061)$ & $(0.186)$ & $(0.382)$ & $(0.082)$ & $(-)$ & $(0.235)$ \\
\hline \multirow{2}{*}{$\begin{array}{l}\text { GDP per capita (U.S. } \\
\text { dollars per capita) }\end{array}$} & -0.602 & 0.780 & 0.673 & 0.796 & -0.117 & 1 \\
\hline & $(0.000)$ & $(0.000)$ & $(0.000)$ & $(0.000)$ & $(0.235)$ & $(-)$ \\
\hline
\end{tabular}

Source: Own calculations.

Note: Pair correlations are in bracets.

Table 4. Regression models of dependence of the size of the shadow economy ( $5 \%$ level of significance)

\begin{tabular}{l|c|c|c|c}
\hline \multicolumn{1}{l}{ Variables } & $\begin{array}{c}1 . \text { model } \\
(2012)\end{array}$ & $\begin{array}{c}\text { 2. model } \\
(2012)\end{array}$ & $\begin{array}{c}\text { 3. model } \\
(2013)\end{array}$ & \multicolumn{1}{c}{$\begin{array}{c}\text { 4. model } \\
(2013)\end{array}$} \\
\hline \multirow{3}{*}{$\begin{array}{l}\text { The institutional } \\
\text { environment, value }\end{array}$} & -4.526 & -4.495 & -4.740 & -4.551 \\
& $(2.162)$ & $(2.151)$ & $(2.242)$ & $(2.237)$ \\
& -0.255 & -0.254 & -0.261 & -0.251 \\
\hline \multirow{3}{*}{ Total tax rate, \% of profits } & & $\mathbf{0 . 0 5 7}$ & & $\mathbf{0 . 0 5 8}$ \\
& & $(0.041)$ & & $(0.043)$ \\
& & 0.109 & & 0.105 \\
GDP per capita (U.S. dollars & -0.0003 & -0.0003 & -0.0003 & -0.0003 \\
per capita) & $(0.0001)$ & $(0.0001)$ & $(0.0001)$ & $(0.0001)$ \\
& -0.413 & -0.402 & -0.398 & -0.394 \\
\hline Constant & 57.185 & 54.375 & 58.120 & 54.743 \\
& $(7.648)$ & $(7.868)$ & $(7.875)$ & $(8.235)$ \\
\hline $\mathrm{R}^{2}$ & 0.400 & 0.412 & 0.390 & 0.400 \\
\hline
\end{tabular}

Source: Own calculations.

Note: Standard errors are specified in brackets; standardised coefficients are bold. 
inferring with $95 \%$ reliability that adding total tax rate as a variable in the model does not enhance the quality of the model.

\section{1. model}

The variation in the size of the shadow economy is explained by $40 \%$ of the variation in value of the institutional environment and GDP per capita. If the value of the institutional environment of a country increases by 1 unit, then the size of the shadow economy will decrease on average by 4.526 units.

\section{2. model}

The variation in the size of the shadow economy is explained by $41.2 \%$ of the variation in value of the institutional environment, GDP per capita and total tax rate.

\section{3. model}

The variation in the size of the shadow economy is explained by $39 \%$ of the variation in value of the institutional environment and GDP per capita. If the value of the institutional environment of the country increases by 1 unit, then the size of the shadow economy will decrease on average by 4.740 units.

\section{4. model}

The variation in the size of the shadow economy is explained by $40 \%$ of the variation in value of the institutional environment, GDP per capita and total tax rate.

Models 1 and 3 are significant in accordance with their parameters and reliable by $95 \%$. According to the White test, the heteroscedasticity in models' residuals is absent.

To summarise the results, it can be stated that a sample of 105 countries with different levels of development proved our thesis that the institutional environment and the size of the shadow economy have a stronger correlation than total tax burden and the size of the shadow economy.

\subsection{Scandinavian and developing countries as examples}

The significance of the institutional environment in determining the size of the shadow economy can be also disclosed by juxtaposing utterly disparate countries in terms of the quality of institutions. By comparing developed Scandinavian countries with less developed European countries, it can be noticed that in spite of a heavy tax burden in Sweden, Norway and Finland, the scope of the shadow economy in these countries is considerably lower than in less developed countries such as Albania, Moldova and Kazakhstan, in which total tax rates are distinctly lower (Figure 1).

This phenomenon can be justified by contrasting other factors which determine the size of the shadow economy. For instance, the states under comparison 


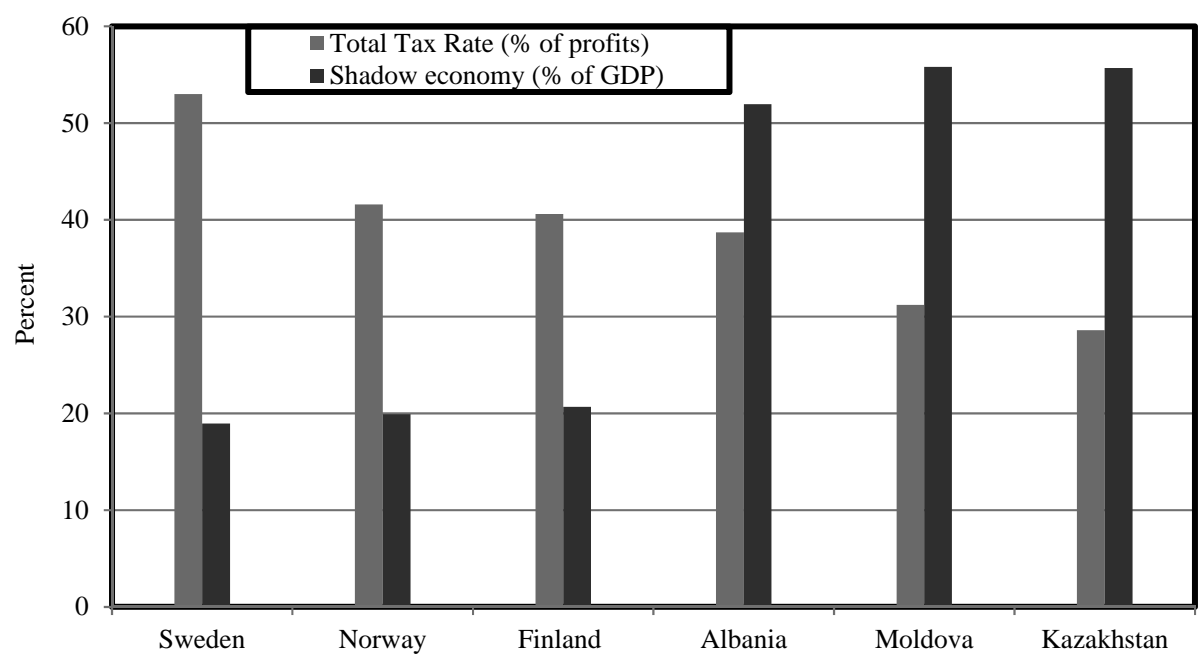

Figure 1. Size of the shadow economy and total tax rate in European countries, 2013

Source: Based at Schneider (2016) and Schwab (2013).

substantially differ in terms of the level of trust in politicians and the number of irregular payments and bribes which define the quality of the institutional environment in the country. Thus, according to the GCR the Scandinavians take the leading positions among 148 countries in the rating of the quality of institutions whereas Kazakhstan, Albania, and Moldova occupy far more modest positions (Table 5).

Table 5. Rank of the institutional environment (out of 148 countries), 2013

\begin{tabular}{lccc}
\hline Country & $\begin{array}{c}\text { Rank of the institutional } \\
\text { environment }\end{array}$ & Trust in politicians & $\begin{array}{c}\text { Irregular payments and } \\
\text { bribes }\end{array}$ \\
\hline Finland & 1 & 7 & 2 \\
Sweden & 5 & 6 & 10 \\
Norway & 6 & 4 & 6 \\
Kazakhstan & 55 & 35 & 65 \\
Albania & 118 & 99 & 118 \\
Moldova & 122 & 118 & 114 \\
\hline
\end{tabular}

Source: Based at Schwab (2013).

The Scandinavians, unlike the other countries under comparison, concede and agree to redistribute considerable volume of tax payments in favour of the state since they have managed to create reciprocal beneficial relations between the citizens and politicians and this can be approved by examining their positions 
in the rank of trust in politicians. The Scandinavians are confident that the state institutions provide all the necessary public benefits.

The aforementioned comparison clearly exemplifies that the tax burden alone cannot be a representative determinant of the shadow economy and other factors must be taken into consideration in analysing the shadow economy as well to derive more accurate results of research. These factors have a synergy effect in the same institutional conditions that makes an essential impact on the size of the shadow economy and leads to its expansion whereas in other conditional factors, levelling each other, promote fixing and even narrowing of the scope of the shadow economy.

\subsection{Comparison of the size of the shadow economy and the institutional environment in Russia, India, China and the USA}

While investigating the size of the shadow economy of the leading countries in terms of GDP, Russia is allocated most of all, in which the fraction of the shadow economy in percentage to GDP exceeds the identical indicators of other countries such as the USA, India and China (Figure 2). There is also a remarkable tendency of the share of the shadow economy to growth during the time period from 2000 to 2013. On the contrary, the scales of the shadow economy in the USA, India

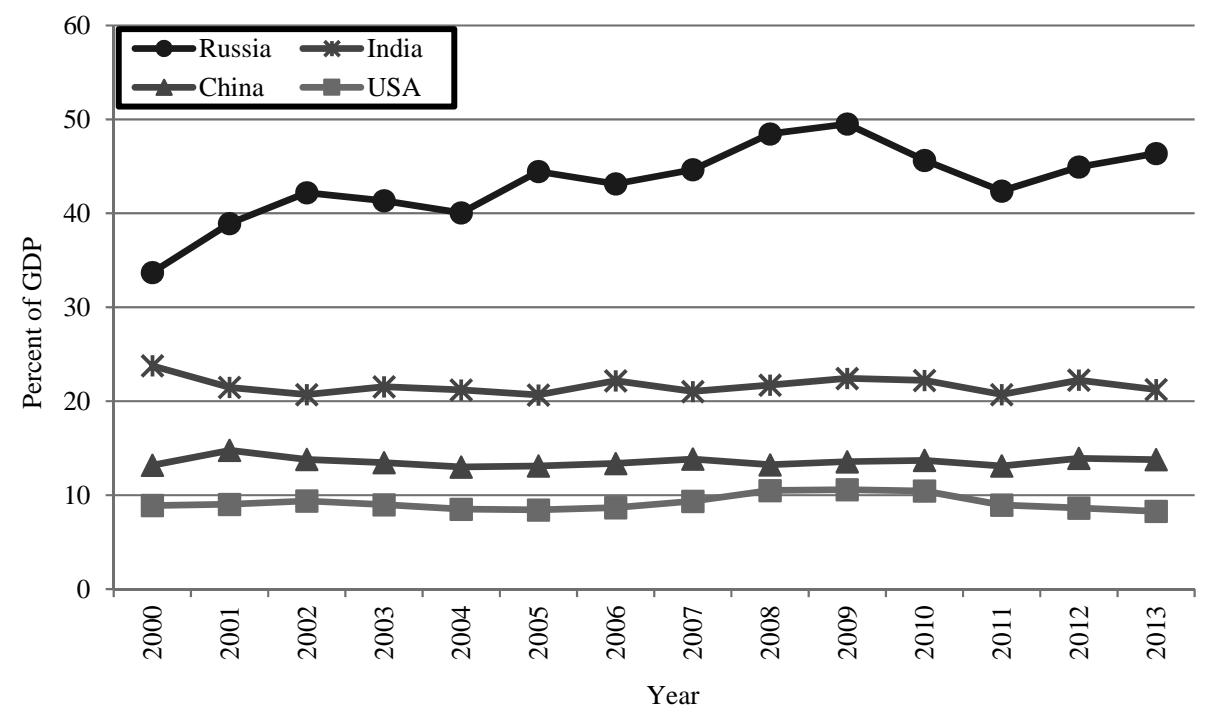

Figure 2. Size of the shadow economy

Source: Based at Schneider (2016). 
and China remained approximately at the same level throughout the identical time interval.

It is important to mention that the level of tax burden cannot justify the strong contrast between the scope of the shadow economy in Russia and in other countries under comparison. For instance, the share of total tax rate in Russia is approximately at the same level as in the USA. Besides, the fraction of the tax burden in Russia is significantly lower than in China and India (Figure 3). In this regard, it is reasonable to specify a remarkable insufficiency of the tax burden as a determinant which can intransigently provide an explanation for differences in the size of the shadow economy.

The enormous size of the shadow economy in Russia can be explained by proceeding not from the distinctions in tax burden but from the other determinant of the shadow economy, that is, the quality of the institutional environment. By juxtaposing the rank of the institutional environment in the countries under comparison (Figure 4), it is possible to notice that the better the quality of the institutional environment, the smaller the scale of the shadow economy. Indeed, among these countries, the leading position in The Rank of Institutional Environment made by The World Economic Forum is taken by the USA, in which a share of the shadow economy is the smallest. After the USA there are China and India, respectively, which are located in the identical sequence when comparing scales of the shadow economy in them. The worst results are shown by Russia, which has taken the

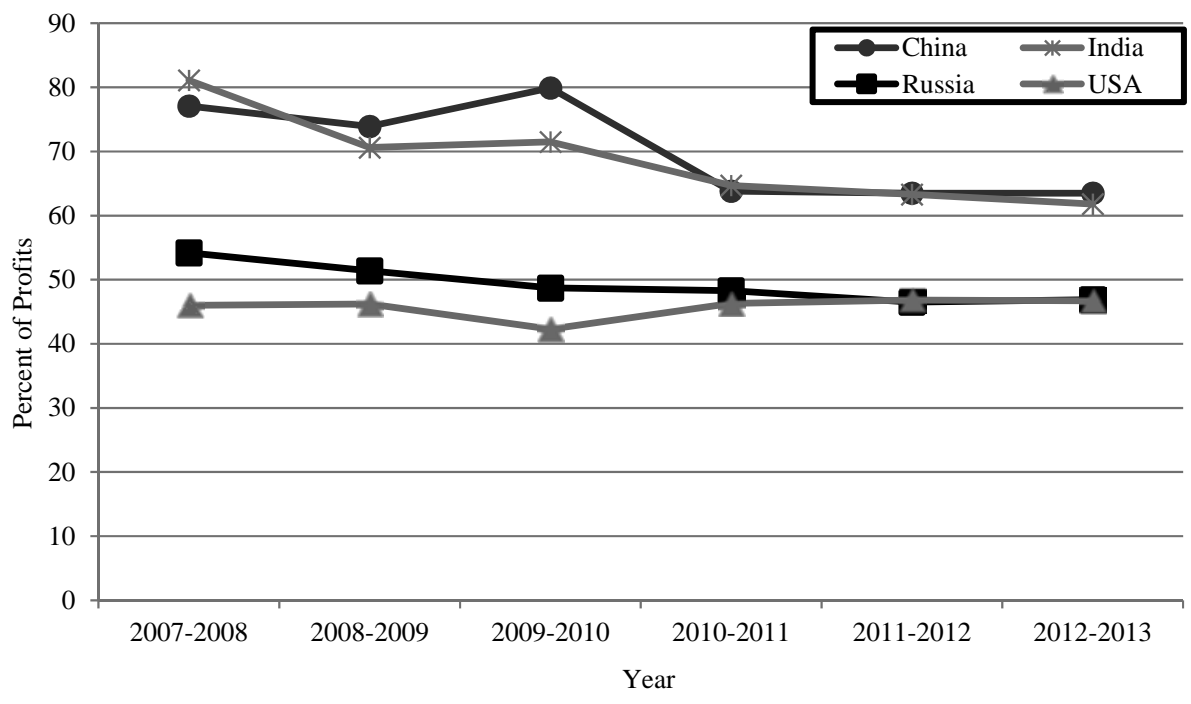

Figure 3. Total tax rate, \% of profits

Source: Based at Schwab (2013). 


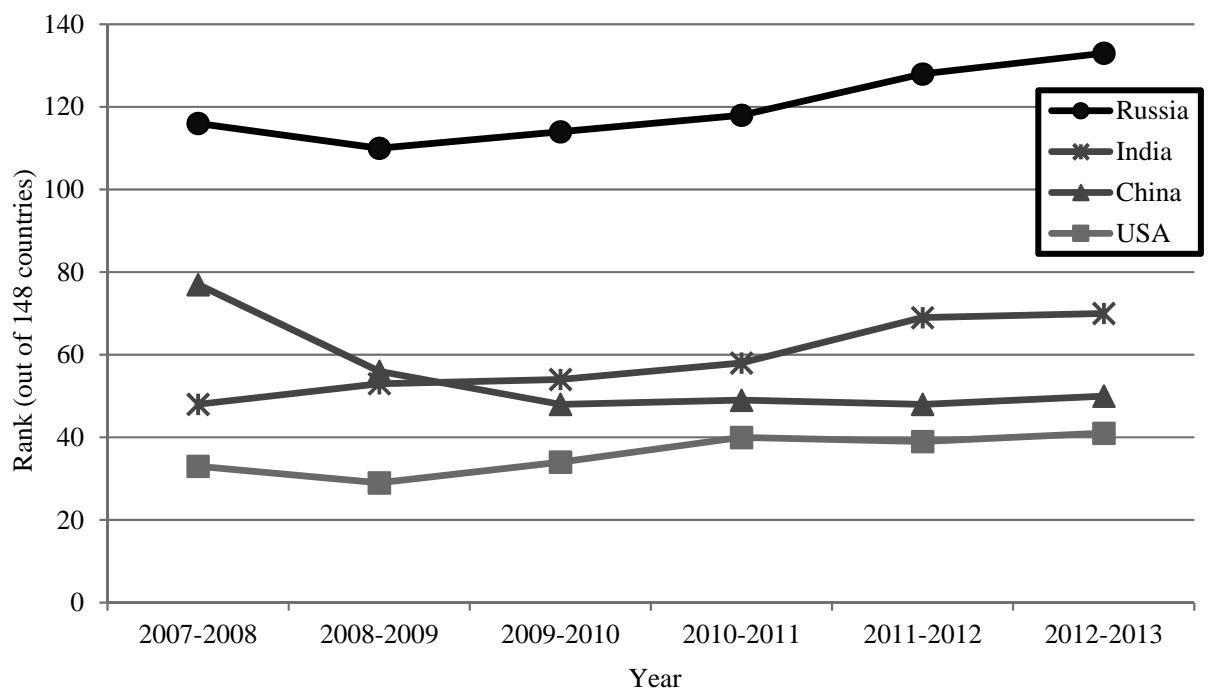

Figure 4. Rank of the institutional environment (out of 148 countries)

Source: Based at Schwab (2013).

lowest positions in the rating for many years that, according to authors, can serve as justification of such immense size of the shadow economy in this country.

We are assured that an improvement in the institutional environment in Russia is capable to reduce the size of the shadow economy which, subsequently, will enable to enhance competitiveness of this country's economy and create auspicious conditions for economic growth.

\section{WEAK INSTITUTIONAL ENVIRONMENT AS THE MAIN CAUSE FOR THE SHADOW ECONOMY IN RUSSIA}

In the early 1990s, there was a widespread assumption in the Russian scientific community that transition of the country to a market economy will lift a ban from entrepreneurship for citizens, and will correspondingly reduce the size of the shadow economy. On the contrary, not only did the collapse of the Soviet Union not promote it, it actually caused the expansion of the size of the shadow economy. This can be confirmed by the rapid emergence and increase in the number of financial pyramids (Ponzi schemes) during that period. Lack of regulating tools capable to coordinate the activity of financial pyramids and to withstand them became the reason for that. In this regard, there was a huge loss in Russian citizens' savings. 
Another negative implication of the collapse of the Soviet Union was the transition of big business to the political elite during privatisation of the state enterprises. The merger of institutes of property with institutes of power set in motion the emergence of large oligarchic structures, redistributing natural resources rent in their favour. Knowing and having certain levers to pressurize the government and using corruption methods along with shadow schemes of doing business, the oligarchical cell promoted the expansion of scales of the shadow economy.

Formation of the present institutional system occurred under the influence of corruption interests of bureaucracy and political interests of the upper echelons of the government. This undermined the credibility of citizens towards the authorities. Confrontation of formal and informal institutes had resulted in the destabilisation of the whole institutional system in general, and that promoted the expansion of the shadow segments. The latter arise when economic agents are excluded from the system of formal institutes, or they try to bypass them.

According to the approach of new institutionalists, changes arise as the result of external shocks such as perturbations in the economy which require reorganisation of institutes (Schneiberg 2005). In Russia, however, external shocks did not promote an improvement of the institutional environment since the economic crisis of 2008-2009 and the oil crisis of 2014-2015 could not bring Russia out of the stagnant state and thereby reduce the scales of the shadow economy.

In this regard it seems that the initiator of institutional changes in Russia should not be the external phenomena, such as crises, but the internal ones, expressed as actions of the authorities. It is construed in the research of Levin - Satarov (2000), who noted the necessity of economic, political and juridical reforms as the tools that are capable to reduce the size of the shadow economy.

We infer that institutional changes which may be expressed, for example, in legalisation of certain segments of the shadow economy, can become one of the ways of decreasing it and mitigating its consequences. The Peruvian economist de Soto (2000) discoursed upon the fact that this can be carried out by means of capital amnesty.

Legalisation of certain types of the shadow activity will provide entrepreneurs with an opportunity to bring their business out of the shadow without any negative consequences for them. It is possible to notice positive effects of such institutional changes employing the example of the Soviet Union modification. In particular, the Cooperation in the USSR Law and Individual Labor Activity Law, which were passed in the late 1980s, were promoted and citizens began to register their shadow kinds of activity, thereby reducing the shadow sector as a whole. The legalised assets promoted their further coordination and mobilisation of resources for further economic development. 
The significant role of the steady decrease in the size of the shadow economy belongs to the effectively functioning entrepreneurial institutions. Its formation in Russia occurred in the period of transformation of the economic system and was caused rather by the institutional necessity, than by the economic expediency. In this regard, a reduction in venality of the bureaucratic apparatus along with the degree of overregulation of business will hopefully promote an increase in efficiancy of the business institutions, and, therefore, will lead to narrowing down the size of the shadow economy.

\section{CONCLUSIONS}

Shadow economy, as a social and economic phenomenon, is represented as an autopoietic (self-reproducing) system which is primarily determined by the following factors: 1) tax burden; 2) tax morale and ethics, corruptness of the bureaucratic apparatus, trust of citizens to public authorities that form the quality of the institutional environment. The institutional environment plays a crucial role in determining the attitude of an economic agent towards the laws that defines whether to obey formal standards and rules or circumvent them. The growth of private transaction expenses resulting from conducting business activity in accordance with all formal requirements promotes runoff of entrepreneurs in the shadow segment. At the same time, an increase in the volume of transaction expenses caused by imperfection of the institutional environment can be ameliorated by the governmental initiatives.

It appears that institutional changes are necessary for a reduction in the size of the shadow economy in developing countries such as in Russia. They are capable to create a structural institutional alternative, which could satisfy the interests of all categories of the population. This compromise can promote coordination of formal and informal institutes that will increase the quality of the institutional environment and, therefore, will serve for economic agents as an impetus for withdrawal from certain types of shadow segments. This can be achieved by building reciprocal relationships between entrepreneurship institute and the authorities through realisation of lines of their interaction. It is also necessary to create an adequate institutional infrastructure for businesses in order to facilitate their functioning which should form the conditions for the development of the competitive environment.

Implementation of the aforementioned actions will provide the higher quality of the institutional environment which will enhance both the level of credibility of citizens towards the state and the degree of trust of authorities towards economic entities and therefore reduce the size of the shadow economy. 


\section{REFERENCES}

Auzan, A. (2017): Institutional Economics: A New Institutional Economic Theory. Moscow: INFRA-M Publication (In Russian).

Cagan, P. (1958): The Demand for Currency Relative to the Total Money Supply. Journal of Political Economy, 66(4): 303-328.

Dreher, A. - Kotsogiannis, C. - McCorriston, S. (2009): How do Institutions Affect Corruption and the Shadow Economy? International Tax and Public Finance, 16(6): 773-796.

De Soto, H. (2000): The Mystery of Capital: Why Capitalism Triumphs in the West and Fails Everywhere Else. London: Bantam Press.

Elgin, C. - Oztunali, O. (2014): Institutions, Informal Economy, and Economic Development. Emerging Markets Finance and Trade, 50(4): 145-162.

Enste, D. H. (2002): The Shadow Economy and Institutional Change in EU Accession Countries: A Two Pillar Strategy for the Challenges Ahead. www.csd.bg/fileSrc.php?id

Feige, E. L. (1979): How Big is the Irregular Economy? Challenge, 22(5): 5-13.

Feige, E. L. (1980): A New Perspective on Macroeconomic Phenomena. The Theory and Measurement of the Unobserved Sector of the United States: Causes, Consequences and Implications. Wassenaar: Netherlands Institute for Advanced Studies.

Friedman, E. - Johnson, S. - Kaufmann, D. - Zoido-Lobaton, P. (2000): Dodging the Grabbing Hand: The Determinants of Unofficial Activity in 69 Countries. Journal of Public Economics, 76(3): 459-493.

Gutmann, P. (1977): The Subterranean Economy. Financial Analysts Journal, 33(6): 26-34.

Giles, D. E. A. (1999): Measuring the Hidden Economy: Implications for Econometric Modelling. Economic Journal, 109(3): 370-380.

Grossman, G. (1977): The Second Economy of the USSR. Problems of Communism, 26(5): 2540.

Hart, K. (1973): Informal Income Opportunities and Urban Employment in Ghana. Journal of Modern African Studies, 11: 61-89.

Hassan, M. - Schneider, F. (2016): Size and Development of the Shadow Economies of 157 Worldwide Countries: Updated and New Measures from 1999 to 2013. IZA Discussion Paper, No. 10281.

Hibbs, D. A. Jr. - Piculescu, V. (2005): Institutions, Corruption and Tax Evasion in the Unofficial Economy. Göteborg University, Department of Economics.

IMF (2012): World Economic Outlook: Growth Resuming, Dangers Remain. Washington, D.C.

IMF (2013): World Economic Outlook: Hopes, Realities, Risks. Washington, D.C.

Johnson, S. - Kaufmann, D. - Shleifer, A. (1997): The Unofficial Economy in Transition. Brookings Papers on Economic Activity, 2: 159-221.

Johnson, S. - Kaufmann, D. - Zoido-Lobatón, P. (1998): Regulatory Discretion and the Unofficial Economy. American Economic Review, Papers and Proceedings, 88(2): 387-92.

Kaldor, N. (1956): Indian Tax Reform: Report of a Survey. Ministry of Finance, Dept. of Economic Affairs.

Katsenelinboigen, A. (1977): Coloured Markets in the Soviet Union. Soviet Studies, 29(1): 62-85.

Kornai, J. (1980): Economics of Shortage. Amsterdam: North-Holland.

Lippert, O. - Walker, M. (1997): The Underground Economy: Global Evidences of Its Size and Impact. Vancouver, B.C.: Frazer Institute.

Levin, M. - Satarov, G. (2000): Corruption and Institutions in Russia. European Journal of Political Economy, 16(1): 113-132.

Luhmann, N. (1990): Essays on Self-Reference. Columbia University Press. 
Mazhar, U. (2015): Does Regulatory Discretion Increase the Unofficial Economy? Evidence from Panel data. Acta Oeconomica, 65(1): 129-141.

Schneiberg, M. (2005): Combining New Institutionalisms: Explaining Institutional Change in American Property Insurance. Sociological Forum, 20(1): 93-137.

Schneider, F. - Williams, C. (2013): The Shadow Economy. London: The Institute of Economic Affairs.

Schneider, F. - Raczkowski, K. - Mróz, B. (2015): Shadow Economy and Tax Evasion in the EU. Journal of Money Laundering Control, 18(1): 34-51.

Schwab, K. (2013): The Global Competitiveness Report 2013-2014. Geneva: Word Economic Forum.

Smith, P. (1994): Assessing the Size of the Underground Economy: The Statistics Canada Perspectives. Statistics Canada, No. 28.

Thomas, J. J. (1992): Informal Economic Activity (LSE Handbooks in Economics). New Jersey, USA: Prentice-Hall. 


\section{APPENDIX}

Table 1. The indicators that define the institutional environment and their weight

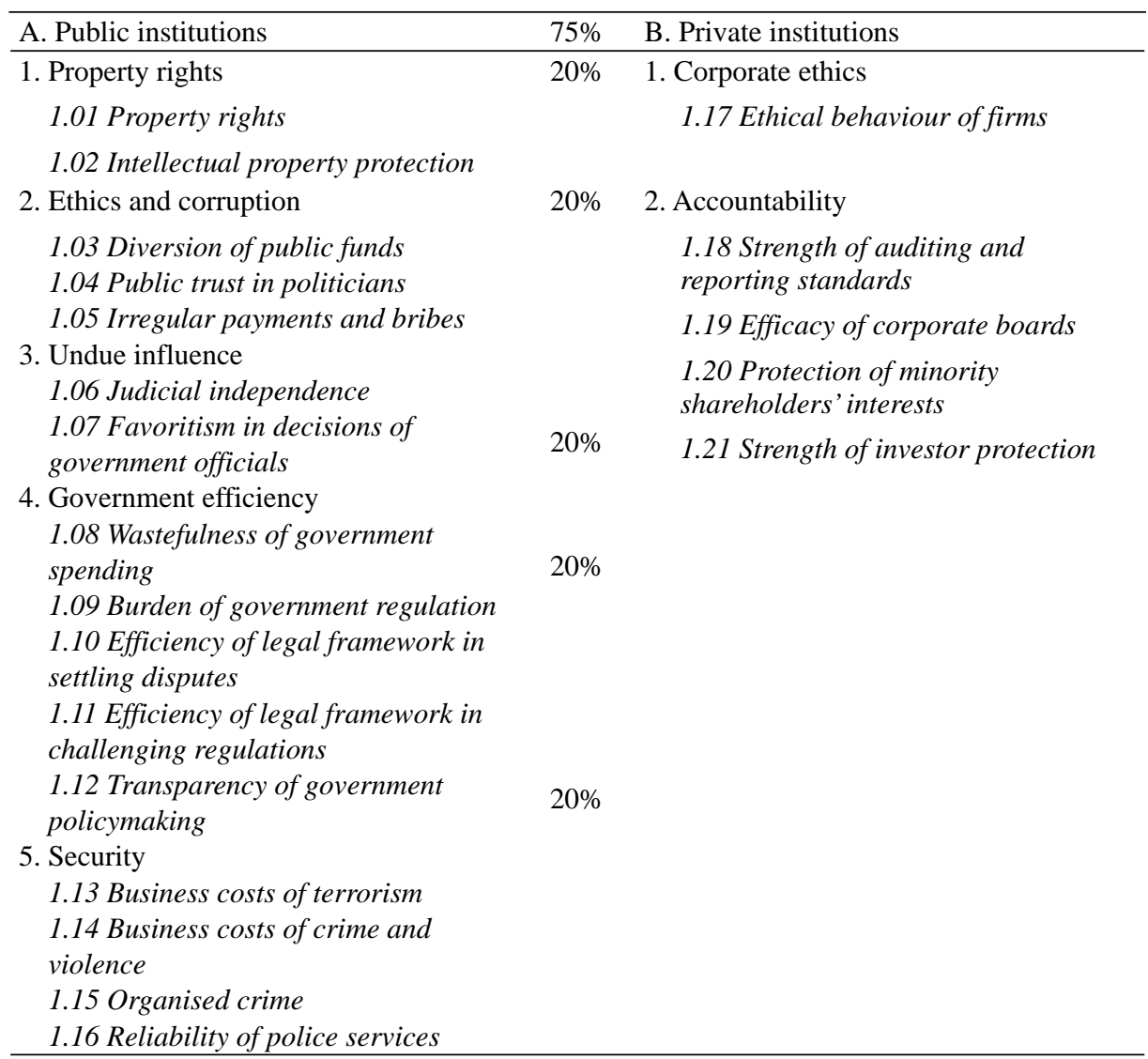

Note: Weight (\%) within immediate parent category.

Source: Made by the authors based on Schwab (2013). 